\title{
Type III Secretion System Genes of Dickeya dadantii 3937 Are Induced by Plant Phenolic Acids
}

\author{
Shihui Yang ${ }^{10}$, Quan Peng ${ }^{1}$, Michael San Francisco ${ }^{2}$, Yongjun Wang ${ }^{1}$, Quan Zeng ${ }^{1}$, Ching-Hong Yang ${ }^{1 *}$
}

1 Department of Biological Sciences, University of Wisconsin-Milwaukee, Milwaukee, Wisconsin, United States of America, 2 Department of Biological Sciences, Texas Tech University, Lubbock, Texas, United States of America

\begin{abstract}
Background: Dickeya dadantii is a broad-host range phytopathogen. D. dadantii 3937 (Ech3937) possesses a type III secretion system (T3SS), a major virulence factor secretion system in many Gram-negative pathogens of plants and animals. In Ech3937, the T3SS is regulated by two major regulatory pathways, HrpX/HrpY-HrpS-HrpL and GacS/GacA-rsmB-RsmA pathways. Although the plant apoplast environment, low $\mathrm{pH}$, low temperature, and absence of complex nitrogen sources in media have been associated with the induction of T3SS genes of phytobacteria, no specific inducer has yet been identified.

Methodology/Principal Findings: In this work, we identified two novel plant phenolic compounds, o-coumaric acid (OCA) and $t$-cinnamic acid (TCA), that induced the expression of T3SS genes dspE (a T3SS effector), hrpA (a structural protein of the T3SS pilus), and $h r p N$ (a T3SS harpin) in vitro. Assays by qRT-PCR showed higher amounts of mRNA of hrpL (a T3SS alternative sigma factor) and $r s m B$ (an untranslated regulatory RNA), but not hrpS (a $\sigma^{54}$-enhancer binding protein) of Ech3937 when these two plant compounds were supplemented into minimal medium (MM). However, promoter activity assays using flow cytometry showed similar promoter activities of hrpN in rsmB mutant Ech148 grown in MM and MM supplemented with these phenolic compounds. Compared with MM alone, only slightly higher promoter activities of $h r p L$ were observed in bacterial cells grown in MM supplemented with OCA/TCA.
\end{abstract}

Conclusion/Significance: The induction of T3SS expression by OCA and TCA is moderated through the rsmB-RsmA pathway. This is the first report of plant phenolic compounds that induce the expression T3SS genes of plant pathogenic bacteria.

Citation: Yang S, Peng Q, San Francisco M, Wang Y, Zeng Q, et al. (2008) Type III Secretion System Genes of Dickeya dadantii 3937 Are Induced by Plant Phenolic Acids. PLoS ONE 3(8): e2973. doi:10.1371/journal.pone.0002973

Editor: Niyaz Ahmed, Centre for DNA Fingerprinting and Diagnostics, India

Received May 27, 2008; Accepted July 23, 2008; Published August 13, 2008

Copyright: (c) 2008 Yang et al. This is an open-access article distributed under the terms of the Creative Commons Attribution License, which permits unrestricted use, distribution, and reproduction in any medium, provided the original author and source are credited.

Funding: This project is supported by grants from a Research Growth Initiative of the University of Wisconsin-Milwaukee and the National Science Foundation (award no. EF-0332163).

Competing Interests: The authors have declared that no competing interests exist.

*E-mail: chyang@uwm.edu

a Current address: BioEnergy Science Center, Oak Ridge National Laboratory, Oak Ridge, Tennessee, United States of America

\section{Introduction}

Dickeya dadantii (formerly Erwinia chrysanthemi) is an opportunistic plant pathogen that causes soft-rot, wilt, and blight diseases on a wide range of plant species. This bacterial pathogen produces a large battery of pectinases for disassembly of the plant cell wall [1]. In phytobacteria, a type III secretion system (T3SS) or hypersensitive response and pathogenicity (Hrp) system, which is responsible for the secretion and translocation of effector proteins into the host cells, is considered a major virulence factor in pathogenesis [2,3]. Genome sequencing has revealed that $D$. dadantii 3937 (Ech3937) has a complete set of genes for the T3SS apparatus. The T3SS in $D$. dadantii has also been reported to play a role in pathogenicity [4-8].

The expression of T3SS genes in phytobacteria is repressed when bacterial cells are cultured in complex media, but is induced in the plant apoplast or in close contact with host cells [9-14]. Expression of T3SS genes is also induced in minimal medium (MM), which is considered to mimic plant apoplastic conditions [14]. The T3SS of Ech3937 is regulated by two major regulatory pathways, the HrpX/HrpY-HrpS-HrpL and the GacS/GacA-
rsmB-RsmA pathways $[15,16]$. In the HrpX/HrpY-HrpS-HrpL pathway, the HrpX/HrpY, which is a two-component system (TCS), activates the gene encoding $\mathrm{HrpS}$, which is a $\sigma^{54}$-enhancer binding protein (Fig. 1). The HrpS protein activates the expression of an alternative sigma factor, $h r p L$. HrpL is required for the expression of genes encoding the T3SS effectors and structural components such as the units of the needle, the needle extension, and the translocon [16]. In the GacS/GacA-rsmB-RsmA pathway, the RsmA protein promotes the decay of $h r p L$ mRNA $[15,17]$. $r s m B$ is an untranslated regulatory RNA that binds RsmA and neutralizes its negative regulatory effect of RsmA by forming an inactive ribonucleoprotein complex [15,17-20]. Although the signal molecule for GacS autophosphorylation is still unknown, the TCS GacS/GacA is reported to up-regulate $\operatorname{rsm} B[15,17]$.

Although several environmental factors (e.g., low $\mathrm{pH}$, low temperature, and the absence of complex nitrogen sources in media) were found to influence the expression of T3SS genes in phytobacteria, no specific plant inducer for hrp gene expression has been identified [12,13,21-24]. Several phenolic acids were reported to play dominant roles in defense signaling in plants $[25,26]$. Recently, efflux pump genes of Ech3937 were found to be 


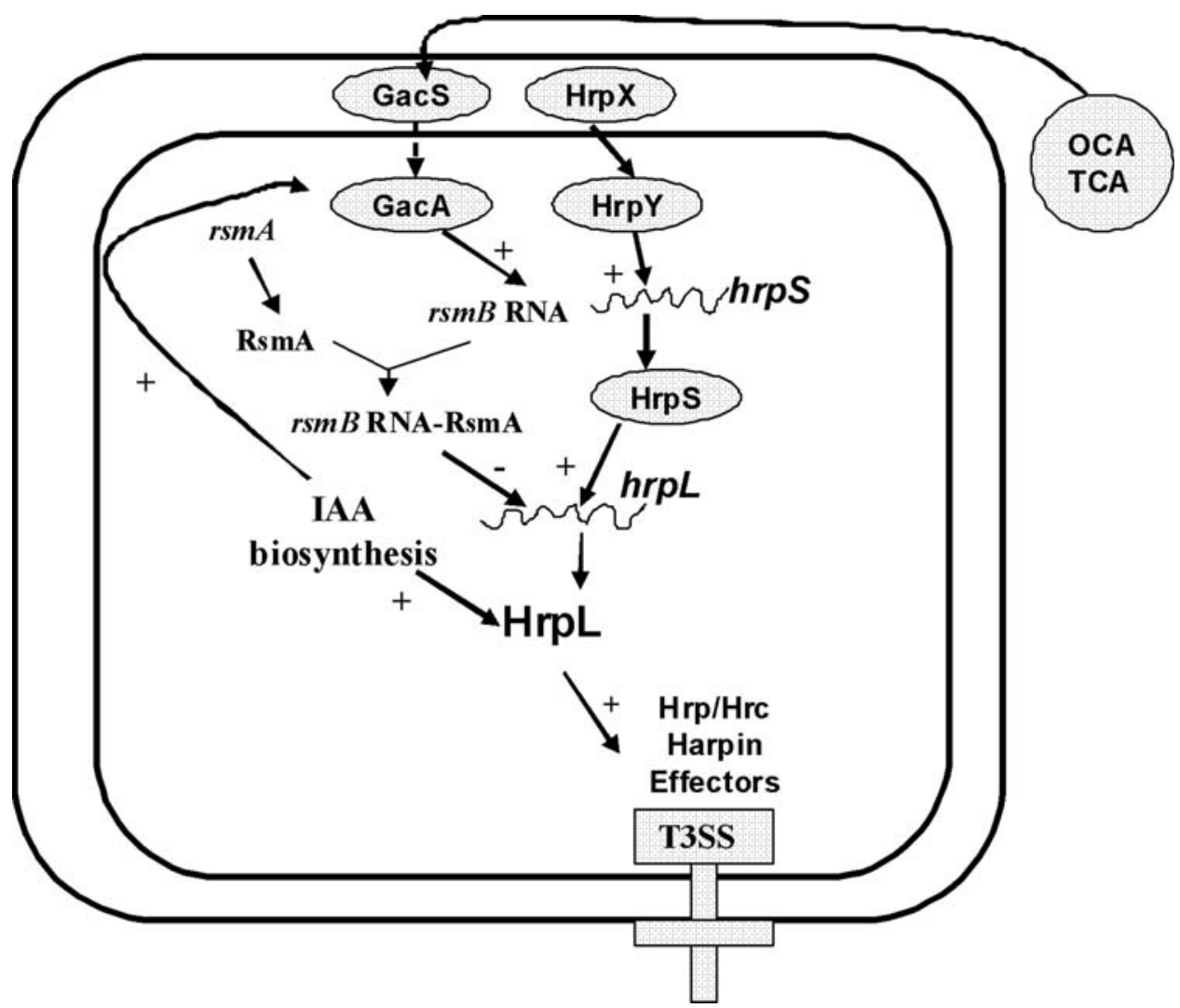

Figure 1. Model of plant phenolic compounds o-coumaric acid (OCA) and $t$-cinnamic acid (TCA) that induce expression of the type III secretion system (T3SS) genes of Dickeya dadantii 3937 (Ech3937). The T3SS and Gac-Rsm regulatory cascades of Ech3937 were adopted as described $[15,16,19,20]$.

doi:10.1371/journal.pone.0002973.g001

induced by phenolic acids [26], which have been suggested to be essential for the pathogenesis of the bacterium by enhancing the resistance to antimicrobial plant chemicals [27]. Since one major role of T3SS of phytopathogens is to neutralize the host defense system during bacterial invasion, it is possible that Ech3937 induces expression of T3SS genes by recognizing certain phenolic compounds in plants. To identify plant compounds that induce the expression of T3SS genes, we focused on elucidating the effect of 0 coumaric acid (OCA), $t$-cinnamic acid (TCA), and salicylic acid (SA) on $h r p$ expression and on the T3SS regulatory pathway.

In this study, two novel plant phenolic compounds, OCA and TCA, that induce the expression T3SS genes of Ech3937, is described. In addition, the regulatory effect for T3SS gene induction by these two phenolic compounds is elucidated.

\section{Results}

T3SS gene expression is induced by plant phenolic compounds

Our previous efforts to screen the plant up-regulated genes in Ech3937 demonstrated that $d s p E$ and $h r p A$ were expressed in planta [28]. Phenolic compounds constitute an important class of organic substances produced by plants. The phenolic compound SA is a signaling molecule that plays a role in host defenses. OCA and TCA are the biosynthetic precursors of SA and are also reported to induce the expression of defense-related genes in plants [29,30]. We examined OCA, TCA, and SA to elucidate their effect on the expression of T3SS genes. The expression of the T3SS gene $h r p \mathcal{N}$ was examined in MM and MM supplemented with OCA, TCA, and SA, at concentrations of $0.05,0.1$, and $0.2 \mathrm{mM}$, respectively. Compared with minimal $h r p$-inducing medium (MM) alone, the average GFP fluorescence intensity of bacterial cells of Ech3937 (phrpN) (Table 1) was increased approximately 4 -fold when $0.05 \mathrm{mM}$ of OCA and TCA were added to the medium (Fig. 2). The addition of SA did not result in increased GFP fluorescence intensity of Ech3937 (Fig. 2). No obvious inhibition of bacterial growth was observed when OCA, TCA, and SA were added into the MM at the concentration below $0.2 \mathrm{mM}$ (Fig. 2; Supplementary Fig. S1).

Since OCA and TCA induced the expression of $h r p \mathcal{N}$, we further investigated the effect of these two phenolic compounds on the expression of additional T3SS genes $h r p A$ and $d s p E$ by qRT-PCR. Compared with MM alone, a significantly higher amount of $d s p E$ and hrpA mRNA was observed in Ech3937 supplemented with OCA (Fig. 3). As in previous work [31], the promoter activities of Ech3937 were determined by collecting the average GFP fluorescence intensity of total bacterial cells (Total) from a flow cytometry although three parameters were measured, including average GFP fluorescence intensity of total bacterial cells (Total), average GFP fluorescence intensity of GFP expressing bacterial cells $\left(\mathrm{GFP}^{+}\right)$, and the percentage of GFP expressing bacterial cells of the total bacterial cells $\left(\mathrm{GFP}^{+} \%\right)$. Compared with MM alone, the average GFP fluorescence intensity of total bacterial cells (Total) of Ech3937 (phrpA) was doubled when $0.1 \mathrm{mM}$ of OCA and TCA were added to the medium (Table 2). The $m r p$, whose protein product contains an ATPase conserved domain, was used as a reference gene in this study as in previous work [31]. Similar $m r p$ expression was observed in Ech3937 (pmrp) when the bacterial cells were grown in MM and MM supplemented with $0.1 \mathrm{mM}$ OCA and TCA, respectively (Table 2). 
Table 1. Strains, plasmids, and DNA primers used in this study.

\begin{tabular}{|c|c|c|}
\hline Strains, plasmids and primers & Characters or sequences $\left(5^{\prime} \text { to } 3^{\prime}\right)^{a}$ & Reference or source \\
\hline \multicolumn{3}{|l|}{ Strains } \\
\hline \multicolumn{3}{|l|}{ E. coli } \\
\hline E. coli DH5 $\alpha$ & $\mathrm{F}^{-} \phi 80$ lacZAM15 $\triangle$ lacZYA-argFU169 deoR recA1 endA1 hsdR17 phoA supE44 thi-1 gyrA96 relA1 $\lambda^{-}$ & Invitrogen, CA \\
\hline E. coli TOP10 & $\begin{array}{l}\left.\mathrm{F}^{-} \text {mcrA } \Delta m r r-h s d R M S-m c r B C\right) \text { } \phi 80 l a c Z \Delta M 15 \Delta l a c X 74 \text { deoR recA1 araD139 } \triangle \text { (ara-leu)7679 galU } \\
\text { galK rpsL endA1 nupG }\end{array}$ & Invitrogen, CA \\
\hline \multicolumn{3}{|l|}{ D. dadantii } \\
\hline Ech3937 & Wild type, Saintpaulia (African violet) isolate & Hugouvieux-Cotte-Pattat, $\mathrm{N}$. \\
\hline Ech-Rif & Ech3937 rifampicin resistant random mutant & [15] \\
\hline Ech137 & $\triangle g a c A:$ kan constructed from Ech-Rif; $\mathrm{Km}^{\mathrm{R}}$ & [15] \\
\hline Ech138 & $\triangle i a a M:: k a n ; \mathrm{Km}^{\mathrm{R}}$ & [15] \\
\hline Ech148 & transposon miniHimar $R B 1$ insertion in $r s m B, \mathrm{Km}^{\mathrm{R}}$ & This work \\
\hline Ech149 & transposon miniHlimar $R B 1$ insertion in gacS, $\mathrm{Km}^{\mathrm{R}}$ & This work \\
\hline Ech3937 (pAT) & Ech3937 containing pPROBE-AT & {$[33,34]$} \\
\hline Ech3937 (phrpA) & Ech3937 containing phrpA; $A p^{R}$ & This work \\
\hline Ech3937 (phrpN) & Ech3937 containing phrpN; $\mathrm{Ap}^{\mathrm{R}}$ & [32] \\
\hline Ech3937 (phrpL) & Ech3937 containing phrpl; $A p^{R}$ & [32] \\
\hline Ech3937 (phrpS) & Ech3937 containing phrpS; $A p^{R}$ & This work \\
\hline Ech3937 (pmrp) & Ech3937 containing pmrp; $A p^{R}$ & [31] \\
\hline Ech-Rif (phrpA) & Ech-Rif containing phrpA; $A p^{R}$ & [15] \\
\hline Ech137 (phrpA) & Ech137 containing phrpA; $\mathrm{Ap}^{\mathrm{R}} \mathrm{Km}^{\mathrm{R}}$ & [15] \\
\hline Ech138 (phrpN) & Ech138 containing phrpN; $\mathrm{Ap}^{\mathrm{R}} \mathrm{Km}^{\mathrm{R}}$ & [32] \\
\hline Ech148 (phrpN) & Ech148 containing phrpA; $\mathrm{Ap}^{\mathrm{R}} \mathrm{Km}^{\mathrm{R}}$ & This work \\
\hline Ech149 (phrpN) & Ech149 containing phrpA; $\mathrm{Ap}^{\mathrm{R}} \mathrm{Km}^{\mathrm{R}}$ & This work \\
\hline \multicolumn{3}{|l|}{ Plasmids } \\
\hline PPROBE-AT & Promoter-probe vector, $A p^{R}$ & {$[33,34]$} \\
\hline pCR2.1-TOPO & PCR cloning vector, $\mathrm{Ap}^{\mathrm{R}} \mathrm{Km}^{\mathrm{R}}$ & Invitrogen, CA \\
\hline phrpA & pProbe-AT derivative with PCR fragment containing 412-bp $h r p A$ promoter region, $A p^{R}$ & This work \\
\hline phrpN & pProbe-AT derivative with PCR fragment containing $h r p N$ promoter region, $A p^{R}$ & [32] \\
\hline phrpL & pProbe-AT derivative with PCR fragment containing $h r p L$ promoter region, $A p^{R}$ & [32] \\
\hline phrpS & pProbe-AT derivative with PCR fragment containing 709-bp $h r p S$ promoter region, $A p^{R}$ & This work \\
\hline Pmrp & pProbe-AT derivative with PCR fragment containing $m r p$ promoter region, $A p^{R}$ & [31] \\
\hline \multicolumn{3}{|l|}{ Primers } \\
\hline phrpA_F & GTGCCGATAGCCAGTGAT & This work \\
\hline phrpA_R & TGCTGCTGCGTTAGAAAG & This work \\
\hline phrpS_F & CAGATTGTATTTGCGGATTG & This work \\
\hline phrpS_R & CGGATTCATTGCTATTCCTTAT & This work \\
\hline rplU_RTF & GCGGCAAAATCAAGGCTGAAGTCG & [32] \\
\hline rplU_RTR & CGGTGGCCAGCCTGCTTACGGTAG & [32] \\
\hline hrpY_RTF & CGGCGACGGGCGTAATGAA & This work \\
\hline hrpY_RTR & TTTCGGCGATGGCATTGACC & This work \\
\hline hrpS_RTF & TGGAAGGCGAAACCGGCACC & This work \\
\hline hrpS_RTR & GCACGGCGGCGCAGTTCAC & This work \\
\hline hrpL_RTF & GATGATGCTGCTGGATGCCGATGT & [32] \\
\hline hrpL_RTR & TGCATCAACAGCCTGGCGGAGATA & [32] \\
\hline hrpA_RTF & CAGCAATGGCAGGCATGCAG & [32] \\
\hline hrpA_RTR & CTGGCCGTCGGTGATTGAGC & [32] \\
\hline dspE_RTF & GATGGCGGAGCTGAAATCGTTC & [32] \\
\hline dspE_RTR & СCTTGCCGGACCGCTTATCATT & [32] \\
\hline rsmB_RTF & AGAGGGATCGCCAGCAAGGATTGT & This work \\
\hline rsmB_RTR & CGTTGGAGCAGTCCCGCTACC & This work \\
\hline gacA_RTF & GCG CTG CCC AGG AAC GT CT & This work \\
\hline gacA_RTR & CGG CCG TGG GTG GAG TCA T & This work \\
\hline
\end{tabular}

${ }^{\mathrm{a}} \mathrm{Ap}{ }^{\mathrm{R}}$, ampicillin resistance; $\mathrm{Km}^{\mathrm{R}}$, kanamycin resistance.

doi:10.1371/journal.pone.0002973.t001 

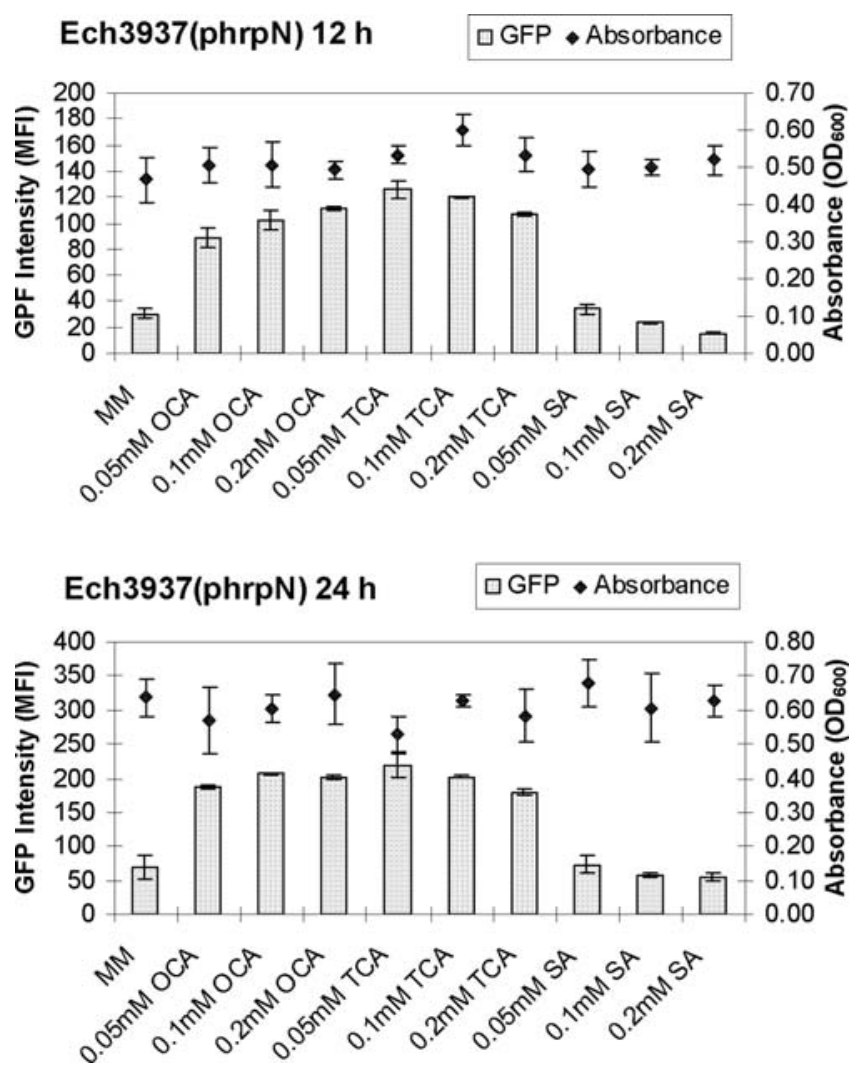

Figure 2. The promoter activities of $h r p N$ in Dickeya dadantii 3937 (Ech3937) grown in MM and MM supplemented with 0.05 , 0.1 , and $0.2 \mathrm{mM}$ OCA, TCA, and SA at $12 \mathrm{~h}$ and $24 \mathrm{~h}$ postinoculation. GFP intensity was determined on gated populations of bacterial cells by flow cytometry and analyzed with the Cell Quest software (BD Biosciences, San Jose, CA). The growth of Ech3937 in MM supplemented with different concentrations of OCA, TCA and SA was recorded.

doi:10.1371/journal.pone.0002973.g002
The effect of phenolic compounds at levels relevant in plants can induce T3SS

We analyzed whether the effect of phenolic compounds is at levels that are physiologically relevant in plants. The potato plant is one of the natural hosts of $D$. dadantii. Montesano et al. [29] reported that the concentration of the phenolic compound TCA in healthy potato leaves was approximately $0.5 \mu \mathrm{M}$, and that TCA accumulated to $10 \mu \mathrm{M}$ in the leaves after exposure to cell-free culture filtrate $(\mathrm{CF})$ of the phytopathogen E. carotovora. To investigate whether the level of the phenolic compounds in plants is able to induce the expression of the T3SS gene $h r p \mathcal{N}$, we further examined its expression with concentrations of TCA equivalent to that in potato leaves. Ech3937 (phrpN) was grown in MM supplemented with $0.2,0.5,5$ and $10 \mu \mathrm{M}$ of TCA, respectively. Compared with Ech3937 (phrpN) in MM alone, a 1.5- to 1.8-fold increase of GFP intensity was observed in the bacterial cells grown in MM supplemented with 0.2 and $0.5 \mu \mathrm{M}$ TCA (Table 3). Compared with Ech3937 (phrpN) in MM, a 3- to 3.5-fold higher GFP intensity was observed in the bacterial cells grown in MM supplemented with 5 and $10 \mu \mathrm{M}$ of TCA (Table 3). These observations suggest that physiologically relevant concentrations of phenolic acids can induce $h r p \mathcal{N}$.

\section{Effect of OCA on IAA biosynthesis pathway}

Since an induction of the expression of $h r p A, h r p \mathcal{N}$ and $d s p E$ was observed in Ech3937, the regulatory mechanism of these phenolic compounds on the T3SS pathway was investigated. Our previous work demonstrated that the expression of T3SS genes $d s p E$, $h r p A$, and $h r p \mathcal{N}$ was reduced in an iaaM mutant Ech138; iaaM encodes an enzyme in the pathway for indole-3-acetic acid (IAA) biosynthesis [32]. To investigate whether IAA biosynthesis is involved in induction of T3SS by the phenolic compounds, the expression of $h r p \mathcal{N}$ in the wild-type Ech3937 and Ech 138 was compared with the addition of OCA. As expected, the expression of $h r p \mathcal{N}$ was reduced in an iaaM mutant background. However, a similar induction ratio of $h r p \mathcal{N}$ by OCA was observed in wild-type Ech3937 and Ech138 at each time point of bacterial growth (Table 4). These results suggest that OCA does not induce T3SS expression through IAA biosynthesis pathway.

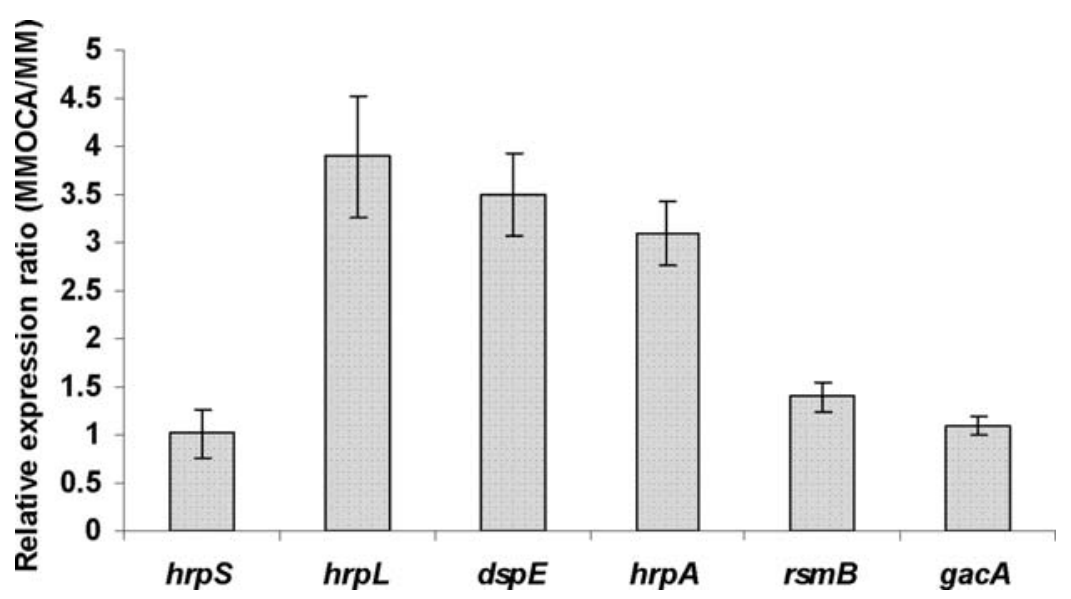

Figure 3. The relative mRNA level of $h r p S, h r p L, d s p E, h r p A, r s m B$, and gacA of Dickeya dadantii 3937 (Ech3937) in MM supplemented with $0.1 \mathrm{mM}$ OCA compared to those in MM without OCA. The amount of mRNA was determined by qRT-PCR. Three replicates were used in this experiment. The $p$-value was calculated using Relative Expression Software Tool as described by Pfaffl et al. [41]. There is no significant difference between MM and MM supplemented with OCA for gene expression of $h r p S$ and gacA with the $p>0.5$, but gene expression of $h r p L, d s p E$, $h r p A$, and $r s m B$ are significantly different between MM and MM supplemented with $0.1 \mathrm{mM}$ OCA with $p<0.003$.

doi:10.1371/journal.pone.0002973.g003 
Table 2. The expression of $h r p A, h r p N$, hrpL, and $h r p S$ of Dickeya dadantii 3937 (Ech3937) in MM, MM supplemented with $0.1 \mathrm{mM}$ OCA (MMOCA), and MM supplemented with $0.1 \mathrm{mM}$ TCA (MMTCA).

\begin{tabular}{|c|c|c|c|c|}
\hline Gene Promoter ${ }^{a}$ & & MM & $M M+O C A$ & MM+TCA \\
\hline \multirow[t]{3}{*}{ Ech3937 (phrpA) ${ }^{b}$} & Total & $41.0 \pm 2.5$ & $82.2 \pm 0.6$ & $77.7 \pm 0.3$ \\
\hline & $\mathrm{GFP}^{+}$ & $120.5 \pm 2.5$ & $170.3 \pm 4.1$ & $167.6 \pm 13.1$ \\
\hline & GFP $^{+} \%$ & $31.0 \pm 1.8$ & $46.5 \pm 1.1$ & $44.8 \pm 3.5$ \\
\hline \multirow[t]{3}{*}{ Ech3937 (phrpN) } & Total & $43.0 \pm 4.3$ & $94.4 \pm 3.2$ & $102.8 \pm 1.1$ \\
\hline & $\mathrm{GFP}^{+}$ & $150.9 \pm 12.5$ & $210.1 \pm 20.8$ & $194.2 \pm 21.6$ \\
\hline & GFP $^{+} \%$ & $27.1 \pm 3.1$ & $44.2 \pm 4.6$ & $52.6 \pm 6.3$ \\
\hline \multirow[t]{3}{*}{ Ech3937 (phrpL) } & Total & $13.7 \pm 1.2$ & $19.1 \pm 0.2$ & $18.8 \pm 1.0$ \\
\hline & $\mathrm{GFP}^{+}$ & $24.8 \pm 1.0$ & $29.8 \pm 0.3$ & $29.5 \pm 0.7$ \\
\hline & $\mathrm{GFP}^{+} \%$ & $41.7 \pm 4.2$ & $54.9 \pm 0.8$ & $54.3 \pm 3.3$ \\
\hline \multirow[t]{3}{*}{ Ech3937 (phrpS) } & Total & $62.6 \pm 1.6$ & $56.4 \pm 0.7$ & $53.5 \pm 1.8$ \\
\hline & $\mathrm{GFP}^{+}$ & $63.7 \pm 1.8$ & $57.3 \pm 0.7$ & $55.0 \pm 1.7$ \\
\hline & $\mathrm{GFP}^{+} \%$ & $98.1 \pm 0.3$ & $98.2 \pm 0.1$ & $97.0 \pm 0.3$ \\
\hline \multirow[t]{3}{*}{ Ech3937 (pAT) } & Total & $1.9 \pm 0.0$ & $2.0 \pm 0.0$ & $1.9 \pm 0.0$ \\
\hline & $\mathrm{GFP}^{+}$ & $28.1 \pm 38.3$ & $35.1 \pm 32.2$ & 0 \\
\hline & GFP $^{+} \%$ & 0 & 0 & 0 \\
\hline
\end{tabular}

${ }^{\mathrm{a}}$ The promoter activities were compared at $12 \mathrm{~h}$ of grown in the media. GFP intensity was determined on gated populations of bacterial cells by flow cytometry. GFP intensity was determined on gated populations $(10,000-15,000$ events) of bacterial cells by flow cytometry. The fluorescence intensities were collected, including average GFP fluorescence intensity of total bacterial cells (Total), average GFP fluorescence intensity of GFP expressing bacterial cells $\left(G_{F P}^{+}\right)$, and the percentage of GFP expressing bacterial cells of the total bacterial cells (GFP $\%$ ).

${ }^{b}$ Values (Mean Fluorescence Intensity) are a representative of at least 3 experiments with similar results. Three replicates were used in this experiment. The value is present as average of three replicates with standard deviation (SD)

doi:10.1371/journal.pone.0002973.t002

\section{Effect of OCA on HrpX/HrpY-HrpS-HrpL pathway}

To investigate whether the OCA induces the T3SS through HrpX/HrpY-HrpS-HrpL pathway, the promoter activities and mRNA levels of $h r p S$ and $h r p L$ of 3937 was examined in MM and MM supplemented with $0.1 \mathrm{mM}$ OCA. Similar $h r p S$ promoter activities and $h r p S \mathrm{mRNA}$ levels were observed between bacterial cells grown in MM and MM supplemented with OCA or TCA (Table 2 and Fig. 3). Compared with MM alone, a slightly higher promoter activity of $h r p L$ was observed in Ech3937 (hrpL) grown in MM supplemented with OCA and TCA (Table 2). However, Ech3937 cultures with the supplementation of $0.1 \mathrm{mM}$ OCA produced about 3 -fold more $h r p L$ mRNAs than those grown in MM alone at $12 \mathrm{~h}$ of growth $(p<0.01)$ (Fig. 3). These results suggest that OCA does not activate T3SS expression through HrpX/Y-HrpS-HrpL pathway and these phenolic compounds induce $h r p L$ expression at a post-transcriptional level.

\section{rsmB up-regulates $h r p L$ gene expression at a post- transcriptional level}

The pPROBE-AT is a promoter-probe reporter plasmid [33,34]. Since the $g f p$ of pPROBE-AT contained its own ribosome binding site, promoter activities of bacterial cells were measured when a promoter region was inserted into this vector [31]. In E. carotovora, RsmA-rsmB regulated $h r p L$ expression at the post-transcriptional level $[15,17]$. In this study, a $r s m B$ mutant Ech 148 was constructed, and a reduced amount of $h r p L$ mRNA was observed in this mutant in comparison with 3937 (Fig. 4). However, similar promoter activity of $h r p L$ was observed between the wild-type bacterium and $\Delta r s m B$ mutant Ech148 (Table 5). Similar promoter activity and mRNA level of $h r p S$ were observed between 3937 and Ech 148 mutant. These results suggested that the reduced amount of $h r p L$ mRNA in Ech 148 was due to the lack of $r s m B$ RNA to quench the activity of RsmA in Ech148. In addition, compared to Ech3937, a lower expression of downstream T3SS genes $h r p A$ and $h r p \mathcal{N}$ was observed in mutant Ech148 (Table 5), which was due to a reduced amount of $h r p L$ mRNA in this mutant (Fig. 4).

Table 3. The expression of hrpN of Dickeya dadantii 3937 (Ech3937) in MM and MM supplemented with different amount of TCA and SA respectively.

\begin{tabular}{|c|c|c|c|}
\hline & & $12 \mathrm{~h}$ & $24 \mathrm{~h}$ \\
\hline \multirow[t]{3}{*}{$\mathbf{M M}^{\mathrm{a}}$} & Total $^{\mathrm{b}}$ & $41.6 \pm 3.6$ & $91.3 \pm 11.5$ \\
\hline & $\mathrm{GFP}^{+}$ & $196.8 \pm 6.6$ & $194.5 \pm 14.3$ \\
\hline & $\mathrm{GFP}^{+} \%$ & $20.0 \pm 2.3$ & $46.1 \pm 7.3$ \\
\hline \multicolumn{4}{|l|}{$\mathbf{T C A}^{\mathrm{a}}$} \\
\hline \multirow[t]{3}{*}{$0.2 \mu \mathrm{M}$} & Total & $65.1 \pm 6.9$ & $163.1 \pm 25.5$ \\
\hline & $\mathrm{GFP}^{+}$ & $200.0 \pm 11.4$ & $250.7 \pm 20.2$ \\
\hline & $\mathrm{GFP}^{+} \%$ & $31.5 \pm 3.2$ & $64.2 \pm 5.4$ \\
\hline \multirow[t]{3}{*}{$0.5 \mu \mathrm{M}$} & Total & $73.5 \pm 4.3$ & $158.8 \pm 21.0$ \\
\hline & $\mathrm{GFP}^{+}$ & $228.0 \pm 8.9$ & $251.4 \pm 18.0$ \\
\hline & $\mathrm{GFP}^{+} \%$ & $31.4 \pm 3.2$ & $62.6 \pm 6.7$ \\
\hline \multirow[t]{3}{*}{$5 \mu \mathrm{M}$} & Total & $134.7 \pm 5.7$ & $266.1 \pm 14.5$ \\
\hline & $\mathrm{GFP}^{+}$ & $287.9 \pm 24.0$ & $357.4 \pm 9.1$ \\
\hline & $\mathrm{GFP}^{+} \%$ & $46.3 \pm 2.2$ & $74.1 \pm 2.9$ \\
\hline \multirow[t]{3}{*}{$10 \mu \mathrm{M}$} & Total & $147.8 \pm 18.5$ & $284.3 \pm 12.3$ \\
\hline & $\mathrm{GFP}^{+}$ & $304.1 \pm 26.7$ & $397.7 \pm 7.7$ \\
\hline & $\mathrm{GFP}^{+} \%$ & $48.0 \pm 3.2$ & $71.1 \pm 3.4$ \\
\hline \multicolumn{4}{|l|}{$S^{a^{a}}$} \\
\hline \multirow[t]{3}{*}{$0.2 \mu \mathrm{M}$} & Total & $53.8 \pm 4.0$ & $105.6 \pm 28.7$ \\
\hline & $\mathrm{GFP}^{+}$ & $199.6 \pm 3.1$ & $219.3 \pm 7.0$ \\
\hline & $\mathrm{GFP}^{+} \%$ & $25.9 \pm 2.5$ & $47.0 \pm 11.8$ \\
\hline \multirow[t]{3}{*}{$0.5 \mu \mathrm{M}$} & Total & $49.6 \pm 6.0$ & $99.6 \pm 18.8$ \\
\hline & $\mathrm{GFP}^{+}$ & $205.0 \pm 2.6$ & $190.9 \pm 14.5$ \\
\hline & $\mathrm{GFP}^{+} \%$ & $23.1 \pm 3.3$ & $50.9 \pm 6.1$ \\
\hline \multirow[t]{3}{*}{$5 \mu \mathrm{M}$} & Total & $50.0 \pm 3.0$ & $97.7 \pm 9.0$ \\
\hline & $\mathrm{GFP}^{+}$ & $200.2 \pm 1.6$ & $194.0 \pm 1.0$ \\
\hline & $\mathrm{GFP}^{+} \%$ & $23.8 \pm 1.3$ & $49.4 \pm 4.5$ \\
\hline \multirow[t]{3}{*}{$10 \mu \mathrm{M}$} & Total & $52.1 \pm 2.4$ & $104.7 \pm 3.2$ \\
\hline & $\mathrm{GFP}^{+}$ & $217.4 \pm 5.0$ & $196.2 \pm 7.4$ \\
\hline & $\mathrm{GFP}^{+} \%$ & $22.9 \pm 0.7$ & $52.5 \pm 3.1$ \\
\hline
\end{tabular}

${ }^{a}$ Minimal medium (MM) alone and MM supplemented with different concentrations of $t$-cinnamic acid (TCA) or salicylic acid (SA).

${ }^{\mathrm{b}}$ The promoter activities of $h r p N$ were measured at 12 and $24 \mathrm{~h}$ of growing in the media. The fluorescence intensities were collected, including average GFP fluorescence intensity of total bacterial cells (Total), average GFP fluorescence intensity of GFP expressing bacterial cells $\left(\mathrm{GFP}^{+}\right)$, and the percentage of GFP expressing bacterial cells of the total bacterial cells (GFP+\%). Three replicates were used in this experiment. The value (Mean Fluorescence Intensity) is present as the average of three replicates with standard deviation. The GFP intensities of Ech3937 (pAT) grown in MM were $2.2 \pm 0$ and $3.4 \pm 0.1$ at $12 \mathrm{~h}$ and $24 \mathrm{~h}$ respectively.

doi:10.1371/journal.pone.0002973.t003 
Table 4. The expression of hrpA or hrpN of Dickeya dadantii 3937 (Ech3937), gacA mutant Ech137, iaaM mutant Ech138, rsmB mutant 148 and gacS mutant Ech149 in MM and MM supplemented with 0.1 mM OCA (MMOCA).

\begin{tabular}{|c|c|c|c|c|c|c|c|}
\hline \multicolumn{2}{|l|}{ Gene Promoter ${ }^{\mathrm{a}}$} & \multicolumn{2}{|l|}{$6 h$} & \multicolumn{2}{|l|}{$12 \mathrm{~h}$} & \multicolumn{2}{|l|}{$24 \mathrm{~h}$} \\
\hline & & MM & MMOCA & MM & MMOCA & MM & MMOCA \\
\hline \multirow[t]{3}{*}{ Ech3937 (pAT) ${ }^{b}$} & Total & $1.9 \pm 0.0$ & $2.0 \pm 0.0$ & $1.9 \pm 0.0$ & $2.0 \pm 0.0$ & $1.8 \pm 0.0$ & $1.9 \pm 0.0$ \\
\hline & $\mathrm{GFP}^{+}$ & $3.9 \pm 6.7$ & $8.0 \pm 7.1$ & $28.1 \pm 38.3$ & $35.1 \pm 32.2$ & $16.3 \pm 7.2$ & $10.7 \pm 0.0$ \\
\hline & $\mathrm{GFP}^{+} \%$ & 0 & 0 & 0 & 0 & 0 & 0 \\
\hline \multirow[t]{3}{*}{ Ech-Rif (phrpA) } & Total & $12.7 \pm 0.2$ & $17.5 \pm 0.2$ & $22.1 \pm 0.4$ & $51.3 \pm 1.5$ & $16.1 \pm 1.2$ & $49.2 \pm 0.8$ \\
\hline & $\mathrm{GFP}^{+}$ & $100.8 \pm 4.5$ & $106.7 \pm 4.8$ & $111.2 \pm 1.7$ & $142.8 \pm 2.1$ & $67.1 \pm 3.7$ & $97.7 \pm 2.4$ \\
\hline & $\mathrm{GFP}^{+} \%$ & $8.1 \pm 0.5$ & $12.0 \pm 0.3$ & $16.2 \pm 0.2$ & $33.4 \pm 0.5$ & $19.7 \pm 2.5$ & $48.0 \pm 0.3$ \\
\hline \multirow[t]{3}{*}{ Ech137 (phrpA) } & Total & $4.7 \pm 0.0$ & $4.9 \pm 0.1$ & $5.5 \pm 0.0$ & $5.9 \pm 0.1$ & $7.6 \pm 0.0$ & $8.3 \pm 0.0$ \\
\hline & $\mathrm{GFP}^{+}$ & $19.3 \pm 4.2$ & $18.3 \pm 3.4$ & $14.9 \pm 0.9$ & $15.4 \pm 0.3$ & $14.0 \pm 0.0$ & $14.3 \pm 0.3$ \\
\hline & $\mathrm{GFP}^{+} \%$ & $2.2 \pm 0.1$ & $2.4 \pm 0.1$ & $4.3 \pm 0.3$ & $6.2 \pm 0.4$ & $18.4 \pm 0.3$ & $23.3 \pm 0.3$ \\
\hline \multirow[t]{3}{*}{ Ech3937 (phrpN) } & Total & $18.8 \pm 2.4$ & $31.4 \pm 3.2$ & $29.5 \pm 3.1$ & $91.4 \pm 8.0$ & $32.5 \pm 2.0$ & $78.1 \pm 7.9$ \\
\hline & $\mathrm{GFP}^{+}$ & $151.3 \pm 9.8$ & $171.7 \pm 10.8$ & $149.2 \pm 8.6$ & $232.6 \pm 36.2$ & $98.9 \pm 6.3$ & $162.4 \pm 11.4$ \\
\hline & $\mathrm{GFP}^{+} \%$ & $10.4 \pm 2.1$ & $16.4 \pm 2.5$ & $17.7 \pm 1.3$ & $38.5 \pm 3.2$ & $30.9 \pm 3.2$ & $46.9 \pm 3.5$ \\
\hline \multirow[t]{3}{*}{ Ech138 (phrpN) } & Total & $5.6 \pm 0.7$ & $9.1 \pm 1.6$ & $11.3 \pm 0.9$ & $32.6 \pm 5.0$ & $17.3 \pm 1.5$ & $38.7 \pm 5.3$ \\
\hline & $\mathrm{GFP}^{+}$ & $68.6 \pm 8.4$ & $69.6 \pm 6.7$ & $95.2 \pm 7.0$ & $115.3 \pm 4.5$ & $90.5 \pm 1.1$ & $105.8 \pm 7.5$ \\
\hline & $\mathrm{GFP}^{+} \%$ & $3.3 \pm 0.6$ & $8.2 \pm 1.6$ & $8.4 \pm 0.3$ & $25.7 \pm 5.4$ & $16.3 \pm 1.8$ & $34.5 \pm 2.6$ \\
\hline \multirow[t]{3}{*}{ Ech148 (phrpN) } & Total & $4.3 \pm 0.1$ & $3.8 \pm 0$ & $4.2 \pm 0.1$ & $3.9 \pm 0.1$ & $4.8 \pm 0.2$ & $4.8 \pm 0.1$ \\
\hline & $\mathrm{GFP}^{+}$ & $16.7 \pm 3.2$ & $15.2 \pm 0.9$ & $22.9 \pm 9.2$ & $27.8 \pm 7.5$ & $22.8 \pm 6.4$ & $23.6 \pm 6.1$ \\
\hline & $\mathrm{GFP}^{+} \%$ & $0.6 \pm 0.1$ & $0.4 \pm 0$ & $1.6 \pm 0.3$ & $0.8 \pm 0.2$ & $2.69 \pm 1.0$ & $2.3 \pm 0.4$ \\
\hline \multirow[t]{3}{*}{ Ech149 (phrpN) } & Total & $4.6 \pm 0.2$ & $3.6 \pm 0.3$ & $4.7 \pm 0.3$ & $3.9 \pm 0.2$ & $4.6 \pm 0.2$ & $5.4 \pm 0.2$ \\
\hline & $\mathrm{GFP}^{+}$ & $14.8 \pm 1.3$ & $26.7 \pm 15.4$ & $17.1 \pm 1.3$ & $36.0 \pm 13.4$ & $32.6 \pm 12.2$ & $37.8 \pm 12.5$ \\
\hline & $\mathrm{GFP}^{+} \%$ & $0.6 \pm 0.3$ & $0.3 \pm 0$ & $2.6 \pm 1.2$ & $0.9 \pm 0.2$ & $2.2 \pm 0.1$ & $2.9 \pm 0.1$ \\
\hline
\end{tabular}

${ }^{a}$ The promoter activities were compared at 6,12 , and $24 \mathrm{~h}$ of bacterial growth. The fluorescence intensities were collected, including average GFP fluorescence intensity of total bacterial cells (Total), average GFP fluorescence intensity of GFP expressing bacterial cells (GFP ${ }^{+}$), and the percentage of GFP expressing bacterial cells of the total bacterial cells $\left(\mathrm{GFP}^{+} \%\right)$.

${ }^{b}$ Values are a representative of at least two experiments with similar results. Three replicates were used in this experiment. The value is present as the average of three replicates with standard deviation (SD).

doi:10.1371/journal.pone.0002973.t004

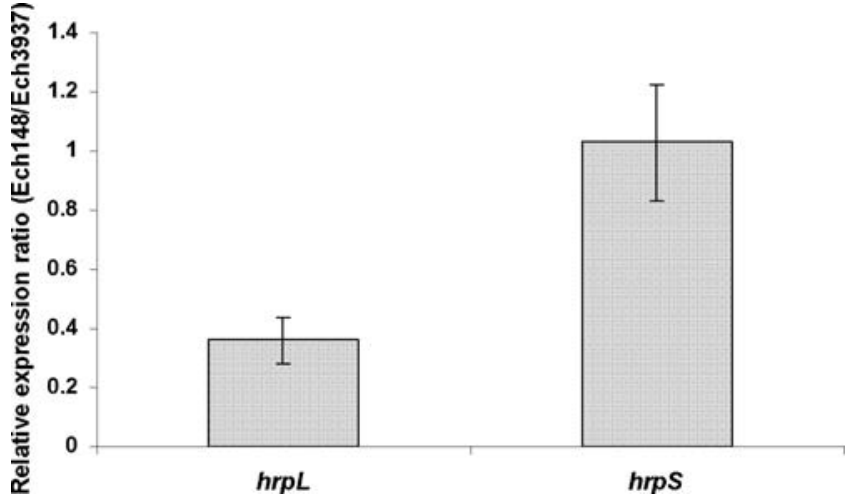

Figure 4. The relative level of mRNA of $h r p L$ and $h r p S$ in Dickeya dadantii 3937 (Ech3937) and rsmB mutant Ech148 grown for 12 h in minimal medium. The amount of mRNA was determined by qRTPCR. Three replicates were used in this experiment. The $p$-value was calculated using Relative Expression Software Tool as described by Pfaffl et al. [41]. There is no significant difference between Ech3937 and Ech148 for gene $h r p S$ with the $p>0.3$, but gene expression of $h r p L$ is significantly different between Ech3937 and Ech148 with $p<0.008$.

doi:10.1371/journal.pone.0002973.g004
OCA induces T3SS through rsmB-RsmA pathway

The TCS GacS/GacA up-regulates rsmB and RsmA-rsmB regulates $h r p L$ at the post-transcriptional level (Fig. 1). To investigate if OCA induces the T3SS through the RsmA-rsmB pathway, the promoter activities of $h r p A$ or $h r p \mathcal{N}$ were compared in the wild-type bacterium, $\Delta r s m B$ mutant Ech148, $\Delta$ gac $S$ mutant Ech149 and $\triangle$ gacA mutant Ech137 carrying phrpA or phrpN grown in MM and MM supplemented with OCA respectively. The wild-type showed a higher GFP intensity grown in MM supplemented with OCA in comparison to MM alone. However, similar GFP intensity was observed in Ech137, Ech148 and Ech149 cells grown in MM and MM supplemented with OCA at each time point of bacterial growth (Table 4). The effect of OCA on the expression of $g a c A$ and $r s m B$ was further examined by qRTPCR. Our results show that, compared with Ech3937 in MM alone (normalized to 1), a significantly higher $r s m B$ mRNA (relative expression ratio $1.4, p=0.003$ ) was observed in the bacterium grown in MM supplemented with OCA (Fig. 3). However, no significant difference in the level of $g a c A$ mRNA was observed in Ech3937 grown in MM and MM supplemented with OCA (Fig. 3). These results suggest the OCA and TCA induce the T3SS through the $r s m B$-RsmA pathway. 
Table 5. The promoter activities of $h r p S, h r p L, h r p A$ and $h r p N$ of Dickeya dadantii 3937 (Ech3937) and rsmB mutant Ech148 grown in minimum medium.

\begin{tabular}{|c|c|c|c|}
\hline Gene Promoter $^{a}$ & & $6 \mathrm{~h}$ & $12 \mathrm{~h}$ \\
\hline \multirow[t]{3}{*}{ Ech3937 (pAT) ${ }^{b}$} & Total & $2.1 \pm 0.1$ & $2.9 \pm 0.6$ \\
\hline & $\mathrm{GFP}^{+}$ & $12.6 \pm 1.6$ & $29.9 \pm 10.3$ \\
\hline & $\mathrm{GFP}^{+} \%$ & 0 & 0 \\
\hline \multirow[t]{3}{*}{ Ech3937 (phrpS) } & Total & $35.9 \pm 1.1$ & $107.4 \pm 0.9$ \\
\hline & $\mathrm{GFP}^{+}$ & $39.6 \pm 0.9$ & $108.0 \pm 1.1$ \\
\hline & $\mathrm{GFP}^{+} \%$ & $88.0 \pm 1.1$ & $99.5 \pm 0.2$ \\
\hline \multirow[t]{3}{*}{ Ech148 (phrpS) } & Total & $30.6 \pm 2.0$ & $90.6 \pm 3.3$ \\
\hline & $\mathrm{GFP}^{+}$ & $33.1 \pm 1.9$ & $90.9 \pm 3.4$ \\
\hline & $\mathrm{GFP}^{+} \%$ & $90.4 \pm 1.8$ & $99.8 \pm 0.1$ \\
\hline \multirow[t]{3}{*}{ Ech3937 (phrpL) } & Total & $4.7 \pm 0.2$ & $10.0 \pm 1.1$ \\
\hline & $\mathrm{GFP}^{+}$ & $16.3 \pm 1.2$ & $16.5 \pm 2.2$ \\
\hline & $\mathrm{GFP}^{+} \%$ & $3.3 \pm 0.4$ & $34.1 \pm 3.2$ \\
\hline \multirow[t]{3}{*}{ Ech148 (phrpL) } & Total & $5.3 \pm 0.0$ & $9.0 \pm 0.1$ \\
\hline & $\mathrm{GFP}^{+}$ & $14.3 \pm 0.5$ & $14.1 \pm 0.1$ \\
\hline & $\mathrm{GFP}^{+} \%$ & $3.4 \pm 0.2$ & $29.9 \pm 1.1$ \\
\hline \multirow[t]{3}{*}{ Ech3937 (phrpA) } & Total & $7.6 \pm 0.1$ & $90.7 \pm 6.5$ \\
\hline & $\mathrm{GFP}^{+}$ & $58.0 \pm 1.7$ & $176.4 \pm 9.2$ \\
\hline & $\mathrm{GFP}^{+} \%$ & $5.6 \pm 0.2$ & $49.8 \pm 4.8$ \\
\hline \multirow[t]{3}{*}{ Ech148 (phrpA) } & Total & $4.7 \pm 0.1$ & $8.5 \pm 0.1$ \\
\hline & $\mathrm{GFP}^{+}$ & $16.5 \pm 0.5$ & $16.0 \pm 0.2$ \\
\hline & $\mathrm{GFP}^{+} \%$ & $1.5 \pm 0.2$ & $21.6 \pm 0.9$ \\
\hline \multirow[t]{3}{*}{ Ech3937 (phrpN) } & Total & $4.2 \pm 0.3$ & $63.7 \pm 3.4$ \\
\hline & $\mathrm{GFP}^{+}$ & $79.0 \pm 4.7$ & $231.4 \pm 33.0$ \\
\hline & $\mathrm{GFP}^{+} \%$ & $1.9 \pm 0.3$ & $26.6 \pm 2.5$ \\
\hline \multirow[t]{3}{*}{ Ech148 (phrpN) } & Total & $2.5 \pm 0.1$ & $3.84 \pm 0.1$ \\
\hline & $\mathrm{GFP}^{+}$ & $35.3 \pm 6.2$ & $30.3 \pm 1.8$ \\
\hline & $\mathrm{GFP}^{+} \%$ & $0.3 \pm 0.1$ & $1.4 \pm 0.2$ \\
\hline
\end{tabular}

${ }^{a}$ The promoter activities were compared at 6 and $12 \mathrm{~h}$ of bacterial growth. The fluorescence intensities were collected, including average GFP fluorescence intensity of total bacterial cells (Total), average GFP fluorescence intensity of GFP expressing bacterial cells $\left(\mathrm{GFP}^{+}\right)$, and the percentage of GFP expressing bacterial cells of the total bacterial cells $\left(\mathrm{GFP}^{+} \%\right)$.

${ }^{b}$ Values are a representative of three experiments with similar results. Three replicates were used in this experiment. The value is present as the average of three replicates with standard deviation (SD).

doi:10.1371/journal.pone.0002973.t005

\section{Discussion}

Plants have multifaceted strategies to deal with microbial pathogens by producing a wide array of antimicrobial compounds, such as phenolic compounds [26]. In the SA biosynthesis pathway in plants, TCA is converted to OCA through ortho-hydroxylation. SA is produced by $\beta$-oxidation of OCA [35]. An increase of the phenolic acid TCA was observed in potato leaves at $2 \mathrm{~h}$ after exposure to CF from E. carotovorum [29]. In addition, TCA was shown to induce the expression of defense-related genes $d r d-1$ (a defense-related alcohol dehydrogenase), pinII (proteinase inhibitor II), chtB4 (basic chitinase) and chtA2 (acidic chitinase) of potato, suggesting that TCA may play a role in defense signaling in plants. The T3SS is considered one of the major virulence factors in many bacterial pathogens. T3SS delivers effectors into host cells [36]. One major role of T3SS of phytopathogens is to disable the host defense system during bacterial invasion. In this work, an approximately 1.7-fold higher GFP intensity was observed in Ech3937 (phrp N) grown in MM supplemented with $0.5 \mu \mathrm{M}$ of TCA (roughly the level of TCA in potato leaves) in comparison to bacterial cells grown in $\mathrm{MM}$ alone (Table 3). However, an approximately 3-fold higher GFP intensity was observed in the bacterial cells grown in MM supplemented with $5 \mu \mathrm{M}$ of TCA (the level of TCA in potato leaves induced by CF). This result indicates that Ech3937 may modulate its T3SS expression to invade hosts by sensing the basal level of TCA in healthy host plants. In addition, due to the accumulated level of the phenolic compound in hosts caused by bacterial infection, a higher expression of T3SS may be induced in the bacterial cells for a defensive response against the plant responses.

In this study, a higher amount of mRNAs of $d s p E$ and $h r p A$ was observed when OCA or TCA were added into MM (Fig. 3). No induction was observed in $h r p S$ when these two plant phenolic acids were added to the MM. Since a significant increase of mRNA of $h r p L$ but only a slight increase of the $h r p L$ promoter activity of Ech3937 was observed when these two plant phenolic acids were added into the MM (Table 3; Fig. 3), it is plausible that $d s p E, h r p A$ and $h r p \mathcal{N}$ are induced by an alternative regulatory pathway and not the HrpX/HrpY-HrpS pathway. In this study, OCA and TCA were unable to enhance $h r p A$ or $h r p \mathcal{N}$ expression of the $\Delta r s m B, \Delta g a c S$, and $\Delta g a c A$ mutants of Ech3937 (Table 4). In addition, an increased mRNA level of $r s m B$ in the wild-type Ech3937 was observed when OCA and TCA were added in MM (Fig. 3). These results suggest that these phenolic compounds regulate T3SS through $r s m B$-RsmA pathway. Since the expression of $r s m B$ of Ech3937 is up-regulated by TCS GacS/GacA [15], our results suggest that OCA/TCA may induce the T3SS gene expression by modulating the mRNA level of $r s m B$ through activation of GacS/GacA. Compared with MM alone, there was no increase in gacA mRNA of Ech3937 when the bacterial cells were grown in MM supplemented with OCA (Fig. 3). In TCS, the activity of histidine kinase and response regulator is stimulated by the phosphorylation of histidine and aspartate residues of these TCS proteins respectively [37]. In this work, the activation of TCS GacS/GacA by OCA may result from the phosphorylation of the GacA protein through GacS. Thus, the amount of mRNA of gacA may not be increased when OCA is supplemented in MM. In the envZ-ompR TCS, the role of EnvZ is primarily as a phosphodonor for response regulator $\mathrm{OmpR}$ activation [38]. Disruption of env $Z$, the sensor kinase did not reduce the level of mRNA of the response regulator $\operatorname{ompR}$. However, at this stage, we can not rule out the possibility of other unknown regulator(s) affected by OCA and further up-regulating the expression of $r \mathrm{smB}$. Finally, compared with Ech3937 in MM, a slightly higher promoter activity of $h r p L$ was observed in the bacterial cells grown in MM supplemented with OCA. With the complexity of the T3SS regulatory system revealed in Ech3937, we can not rule out that other alternate regulatory pathways may also play a role in T3SS induction by OCA and/or TCA.

In summary, two T3SS inducers, OCA and TCA, were identified in this study. The induction of T3SS gene expression by these two phenolic compounds is moderated through the $r \mathrm{sm} B$ RsmA pathway. With the similarity of these global virulence regulatory systems of T3SS among plant and animal pathogens, the roles of plant phenolic compounds on Ech3937 unveiled in this study will foster efforts for the future development of antimicrobial reagents (e. g., development of phenolic compound analogues that block the T3SS regulatory pathway) and strategies for pathogen control in many fields, including agriculture, medicine, and the food industry. 


\section{Materials and Methods}

\section{Bacterial strains, plasmids, media and chemicals}

The bacterial strains and plasmids used in this study are listed in Table 1. E. coli was grown in LB broth at $37^{\circ} \mathrm{C}$ and $D$. dadantii was grown in $\mathrm{MM}$ at $28^{\circ} \mathrm{C}$ [32]. Antibiotics $(\mu \mathrm{g} / \mathrm{ml})$ used were: ampicillin, 100; kanamycin, 50. Primers used for Polymerase Chain Reaction (PCR) in this report are also listed in Table 1. OCA, TCA and SA were purchased from Sigma-aldrich (St. Louis, MO). A transposon miniHimar RB1 was used to construct a mutant library of 3937 in the Yang Lab (unpublished data). For this purpose, $E$. coli $\mathrm{S} 17-1 \lambda$-pir (pMiniHimar RB1) (E. coli S17-1 $\lambda$-pir cells carrying plasmid pMiniHimar RB1) was used as a donor in mating with Ech3937 [39]. The miniHimar RB1 carries an $\mathrm{R} 6 \mathrm{~K} \gamma$ origin of replication. To locate the disrupted region containing the MiniHimar RB1, the chromosomal DNAs of these mutants were digested by $B a m \mathrm{H} 1$, followed by self-ligation and sequencing [39]. Two of the transposon mutants, $\Delta r s m B$ (Ech148) and $\Delta \operatorname{gac} S$ (Ech149), identified in the mutant library were used in this study.

\section{FACS analysis}

FACS analysis of promoter activity of $h r p A, h r p L, h r p \mathcal{N}$, and $h r p S$ was carried out as described [31]. Briefly, the wild-type Ech3937 and the mutant strains carrying the promoter reporter plasmid were grown on $\mathrm{LB}$ broth at $28^{\circ} \mathrm{C}$ overnight and transferred to appropriate media. For FACS analysis, samples were collected by centrifugation, washed with $1 \mathrm{X}$ phosphate buffer saline, and resuspended in $1 \mathrm{X}$ PBS to ca $10^{6} \mathrm{CFU} / \mathrm{ml}$ prior to being run in a FACS Calibur flow cytometer (BD Biosiences, CA). Among all the flow cytometry assays that we tested, the gated event number of each individual assay was constantly around 10000-15000 events. To avoid debris, electronic background, and undesired clumps in the bacterial samples, a Gate Rl was set up, which was based on light scatter for the flow cytometry assay.

\section{References}

1. Hugouvieux-Cotte-Pattat N, Condemine G, Nasser W, Reverchon S (1996) Regulation of pectinolysis in Enwinia chrysanthemi. Annu Rev Microbiol 50: 213-257.

2. Chang JH, Goel AK, Grant SR, Dangl JL (2004) Wake of the flood: ascribing functions to the wave of type III effector proteins of phytopathogenic bacteria. Curr Opin Microbiol 7: 11-18.

3. Tang X, Xiao Y, Zhou JM (2006) Regulation of the type III secretion system in phytopathogenic bacteria. Mol Plant Microbe Interact 19: 1159-1166.

4. Bauer DW, Bogdanove AJ, Beer SV, Collmer A (1994) Erwinia chrysanthemi hrp genes and their involvement in soft rot pathogenesis and elicitation of the hypersensitive response. Mol Plant Microbe Interact 7: 573-581.

5. Bauer DW, Wei ZM, Beer SV, Collmer A (1995) Erwinia chrysanthemi harpin ${ }_{\text {Ech }}$ : an elicitor of the hypersensitive response that contributes to soft-rot pathogenesis. Mol Plant Microbe Interact 8: 484-491.

6. Lopez-Solanilla E, Llama-Palacios A, Collmer A, Garcia-Olmedo F, RodriguezPalenzuela P (2001) Relative effects on virulence of mutations in the sap, pel, and hrp loci of Enwinia chrysanthemi. Mol Plant Microbe Interact 14: 386-393.

7. Nasser W, Reverchon S, Vedel R, Boccara M (2005) PecS and PecT coregulate the synthesis of $\mathrm{HrpN}$ and pectate lyases, two virulence determinants in Erwinia chrysanthemi 3937. Mol Plant Microbe Interact 18: 1205-1214.

8. Yang CH, Gavilanes-Ruiz M, Okinaka Y, Vedel R, Berthuy I, et al. (2002) hrp genes of Erwinia chrysanthemi 3937 are important virulence factors. Mol Plant Microbe Interact 15: 472-480.

9. Alfano JR, Charkowski AO, Deng WL, Badel JL, Petnicki-Ocwieja T, et al. (2000) The Pseudomonas syringae Hrp pathogenicity island has a tripartite mosaic structure composed of a cluster of type III secretion genes bounded by exchangeable effector and conserved effector loci that contribute to parasitic fitness and pathogenicity in plants. Proc Natl Acad Sci U S A 97: 4856-4861.

10. Alhenc-Gelas M, Gandrille S, Aubry ML, Aiach M (2000) Thirty-three novel mutations in the protein $\mathrm{C}$ gene. French INSERM network on molecular

\section{qRT-PCR analysis}

Bacterial strains were grown in MM. Total RNA from the bacterial cells was isolated by using the TRI reagent method (Sigma, MO) and treated with Turbo DNA-free DNase kits (Ambion, TX) as described [31]. An iScript cDNA Synthesis Kit (Bio-Rad, Hercules, CA) was used to synthesize cDNA from $0.5 \mu \mathrm{g}$ of treated total RNA. The Real Master Mix (Eppendorf, Westbury, NY) was used for qRT-PCR reactions to quantify the cDNA level of target genes in different samples. The $r p l U$ was used as the endogenous control for data analysis [40]. qRT-PCR data were analyzed using Relative Expression Software Tool as described by Pfaffl et al. [41].

\section{Supporting Information}

Figure S1 The growth of Ech3937 (phrpN) in MM and MM supplemented with different concentrations of OCA, TCA and SA. Overnight-cultured Ech3937 (phrpN) cells in Luria Broth were transferred into MM or MM supplemented with OCA, TCA and SA. At $12 \mathrm{~h}$ and $24 \mathrm{~h}$, serial dilutions of bacterial cultures were plated on the Luria Broth agar. The Colony Forming Unit (CFU) per $\mathrm{ml}$ was obtained according to the numbers of the colonies growing on the plates at different dilutions. Three replicates were used in this experiment.

Found at: doi:10.1371/journal.pone.0002973.s001 (0.02 MB TIF)

\section{Acknowledgments}

This work is dedicated to Professor Noel T. Keen. We would like to thank Drs. M. L. P. Collins and M. J. McBride for a critical review of this manuscript. We also thank Nicole Perna of the University of Wisconsin for providing access to the annotated $D$. dadantii genome sequences (https:// asap.ahabs.wisc.edu/asap/ASAP1.htm).

\section{Author Contributions}

Conceived and designed the experiments: CHY. Performed the experiments: SY QP YW QZ CHY. Analyzed the data: SY QP MJSF QZ CHY. Contributed reagents/materials/analysis tools: MJSF. Wrote the paper: CHY.

abnormalities responsible for protein $\mathrm{C}$ and protein S. Thromb Haemost 83: 86-92.

11. Arlat M, Gough CL, Zischek C, Barberis PA, Trigalet A, et al. (1992) Transcriptional organization and expression of the large hrp gene cluster of Pseudomonas solanacearum. Mol Plant Microbe Interact 5: 187-193.

12. Brencic A, Winans SC (2005) Detection of and response to signals involved in host-microbe interactions by plant-associated bacteria. Microbiol Mol Biol Rev 69: 155-194.

13. Francis MS, Wolf-Watz H, Forsberg A (2002) Regulation of type III secretion systems. Curr Opin Microbiol 5: 166-172.

14. Galan JE, Collmer A (1999) Type III secretion machines: bacterial devices for protein delivery into host cells. Science 284: 1322-1328.

15. Yang S, Peng Q Zhang Q Yi X, Choi CJ, et al. (2008) Dynamic Regulation of GacA in Type III Secretion, Pectinase Gene Expression, Pellicle Formation, and Pathogenicity of Dickeya dadantii (Erwinia chrysanthemi 3937). Mol Plant Microbe Interact 21: 133-142.

16. Yap MN, Yang CH, Barak JD, Jahn CE, Charkowski AO (2005) The Erwinia chrysanthemi type III secretion system is required for multicellular behavior. J Bacteriol 187: 639-648.

17. Cui Y, Mukherjee A, Dumenyo CK, Liu Y, Chatterjee AK (1999) rsmC of the soft-rotting bacterium Erwinia carotovora subsp. carotovora negatively controls extracellular enzyme and harpin ${ }_{E c c}$ production and virulence by modulating levels of regulatory RNA $(r s m B)$ and RNA-binding protein (RsmA). J Bacteriol 181: 6042-6052.

18. Chatterjee A, Cui Y, Chatterjee AK (2002) Regulation of Erwinia carotovora $h r p L_{E c c}\left(\right.$ sigma- $\left.L_{E c c}\right)$, which encodes an extracytoplasmic function subfamily of sigma factor required for expression of the HRP regulon. Mol Plant Microbe Interact 15: 971-980.

19. Chatterjee A, Cui Y, Chatterjee AK (2002) RsmA and the quorum-sensing signal, N-[3-oxohexanoyl]-L-homoserine lactone, control the levels of $r s m B$ RNA 
in Erwinia carotovora subsp. carotovora by affecting its stability. J Bacteriol 184: 4089-4095.

20. Chatterjee A, Cui Y, Yang H, Collmer A, Alfano JR, et al. (2003) GacA, the response regulator of a two-component system, acts as a master regulator in Pseudomonas syringae pv. tomato DC3000 by controlling regulatory RNA, transcriptional activators, and alternate sigma factors. Mol Plant Microbe Interact 16: 1106-1117.

21. Aldon D, Genin S (2000) Ralstonia solanacearum-a plant pathogen in touch with its host: Response. Trends in Microbiology 8: 489.

22. Buttner D, Bonas U (2006) Who comes first? How plant pathogenic bacteria orchestrate type III secretion. Curr Opin Microbiol 9: 193-200.

23. Ham JH, Cui Y, Alfano JR, Rodriguez-Palenzuela P, Rojas CM, et al. (2004) Analysis of Enwinia chrysanthemi EC16 pelE::uidA, pelL::uidA, and hrpN::uidA mutants reveals strain-specific atypical regulation of the Hrp type III secretion system. Mol Plant Microbe Interact 17: 184-194.

24. Mota LJ, Sorg I, Cornelis GR (2005) Type III secretion: the bacteria-eukaryotic cell express. FEMS Microbiol Lett 252: 1-10.

25. Fagard M, Dellagi A, Roux C, Perino G, Rigault M, et al. (2007) Arabidopsis thaliana Expresses Multiple Lines of Defense to Counterattack Erwinia chrysanthemi. Molecular Plant-Microbe Interactions 20: 794-805.

26. Ravirala RS, Barabote RD, Wheeler DM, Reverchon S, Tatum O, et al. (2007) Efflux pump gene expression in Erwinia chrysanthemi is induced by exposure to phenolic acids. Mol Plant Microbe Interact 20: 313-320.

27. Barabote RD, Johnson OL, Zetina E, San Francisco SK, Fralick JA, et al. (2003) Enwinia chrysanthemi tol $C$ is involved in resistance to antimicrobial plant chemicals and is essential for phytopathogenesis. J Bacteriol 185: 5772-5778.

28. Yang SH, Perna NT, Cooksey DA, Okinaka Y, Lindow SE, et al. (2004) Genome-wide identification of plant-upregulated genes of Erwinia chrysanthemi 3937 using a GFP-Based IVET leaf array. Molecular Plant-Microbe Interactions 17: 999-1008.

29. Montesano M, Brader G, De Leon ISP, Palva ET (2005) Multiple defence signals induced by Enwinia carotovora ssp carotovora elicitors in potato. Molecular Plant Pathology 6: 541-549.
30. Vidal S, deLeon IP, Denecke J, Palva ET (1997) Salicylic acid and the plant pathogen Enwinia carotovora induce defense genes via antagonistic pathways. Plant Journal 11: 115-123.

31. Peng Q Yang S, Charkowski AO, Yap MN, Steeber DA, et al. (2006) Population behavior analysis of $d s p E$ and pelD regulation in Erwinia chrysanthemi 3937. Mol Plant Microbe Interact 19: 451-457.

32. Yang S, Zhang Q, Guo J, Charkowski AO, Glick BR, et al. (2007) Global effect of indole-3-acetic acid biosynthesis on multiple virulence factors of Erwinia chrysanthemi 3937. Appl Environ Microbiol 73: 1079-1088.

33. Miller WG, Lindow SE (1997) An improved GFP cloning cassette designed for prokaryotic transcriptional fusions. Gene 191: 149-153.

34. Miller WG, Leveau JH, Lindow SE (2000) Improved $g f p$ and inaz broad-hostrange promoter-probe vectors. Mol Plant Microbe Interact 13: 1243-1250.

35. Yalpani N, Leon J, Lawton MA, Raskin I (1993) Pathway of Salicylic Acid Biosynthesis in Healthy and Virus-Inoculated Tobacco. Plant Physiol 103: 315-321.

36. Lindeberg M, Cartinhour S, Myers CR, Schechter LM, Schneider DJ, et al. (2006) Closing the circle on the discovery of genes encoding Hrp regulon members and type III secretion system effectors in the genomes of three model Pseudomonas syringae strains. Mol Plant Microbe Interact 19: 1151-1158.

37. Heeb S, Blumer C, Haas D (2002) Regulatory RNA as mediator in GacA/ RsmA-dependent global control of exoproduct formation in Pseudomonas fluorescens CHA0. J Bacteriol 184: 1046-1056.

38. Park D, Forst S (2006) Co-regulation of motility, exoenzyme and antibiotic production by the EnvZ-OmpR-FlhDC-FliA pathway in Xenorhabdus nematophila. Mol Microbiol 61: 1397-1412.

39. Bouhenni R, Gehrke A, Saffarini D (2005) Identification of genes involved in cytochrome $c$ biogenesis in Shewanella oneidensis, using a modified mariner transposon. Appl Environ Microbiol 71: 4935-4937.

40. Mah TF, Pitts B, Pellock B, Walker GC, Stewart PS, et al. (2003) A genetic basis for Pseudomonas aeruginosa biofilm antibiotic resistance. Nature 426: 306-310.

41. Pfaffl MW, Horgan GW, Dempfle L (2002) Relative expression software tool (REST (c)) for group-wise comparison and statistical analysis of relative expression results in real-time PCR. Nucleic Acids Research 30: e36. 